\title{
PROFIL PERILAKU NARSISME REMAJA SERTA IMPLIKASINYA BAGI BIMBINGAN DAN KONSELING
}

\author{
Wida Widiyanti', M. Solehuddin², Aas Saomah ${ }^{3}$
}

\begin{abstract}
The behavior of narcissism on adolescent became one of some focuses by teachers of Guidance and Counseling to more comprehend the problem of students. The approach of Freudian traditional psychodynamic put narcissism as a failure of running progress passing through lower level in psychosexual development. The research is aimed to know general description of student narcissism in adolescence. The approach that was used in this research is quantitative approach where the research method is descriptive method. The result of research showed that generally narcissism level of students is categorized average, where it was obtained by data collection tool exactly using questionnaire narcissism behavior that were scattered randomly to students grade VIII SMP Negeri 29 Bandung year 2015/2016. Based on the research result, some student was found in high category, it means that should to hand over the case to the expert who can help more accurate. Meanwhile, some students who are in average and low category need some guidance service for preventing narcissism behavior that psychologically disrupt them.
\end{abstract}

Keywords: Adolescent, Guidance and Counseling, Narcissism.

\section{PENDAHULUAN}

Dewasa ini, istilah narsisme lebih dikenal oleh masyarakat umum sebagai gambaran individu dengan rasa percaya diri yang tinggi. Pada dasarnya narsisme merupakan bentuk aktulasisasi diri seseorang yang mencintai dirinya sendiri secara berlebihan. Istilah narsisme dalam psikologi dapat digolongkan pada salah satu gangguan kepribadian. Hal ini ditunjukan bahwa individu menampillkan suatu pola yang berlebihan dan rasa percaya diri yang tinggi serta cenderung tidak dapat menyesuaikan dengan keadaan diri sendiri, sehingga dalam kehidupan sosial cenderung menonjolkan kenyamanan pada kesendirian dan individualistik.

Kernberg (1980) mengungkapkan bahwa perilaku narsisme terjadi ketika adanya kerancuan antara diri yang ideal dan diri sejati, kendati demikian narsistik bukan merupakan gangguan kepribadian yang berat karena masih adanya

\footnotetext{
' Departemen Psikologi Pendidikan dan Bimbingan Fakultas Ilmu Pendidikan (FIP) Universitas Pendidikan Indonesia; widawidiyanti902@yahoo.com.

2 Departemen Psikologi Pendidikan dan Bimbingan FIP Universitas Pendidikan Indonesia; msolehuddin@upi.edu.

${ }^{3}$ Departemen Psikologi Pendidikan dan Bimbingan FIP Universitas Pendidikan Indonesia; aas.saomah@upi.edu.
} 
struktur kohesif yang berada dalam diri individu. Lebih lanjut Vaknin (2007: 12) mendefenisikan narsisme sebagai achievement-oriented and proud of his or her possessions and accomplishments. Artinya bahwa narsis lebih berfokus pada rasa bangga terhadap dirinya sendiri.

Menurut Lam (20I2) nasisme berasal dari konsep diri dan rasa percaya diri, rasa percaya diri tersebut diaktualisasikan melalui perilaku seperti percaya diri sebagai individu yang unik, memiliki intelegensi yang lebih, dan memiliki potensi lebih dari orang lain sehingga cenderung tidak menerima diri sendiri karena berperilaku secara berlebihan dari kemampuan serta keadaan yang sebenarnya. Kompensasi narsistik cenderung negatif, pencarian untuk meniadakan perasaan mendalam mengenai inferioriti dan berusaha untuk menciptakan suatu ilusi menjadi individu yang berkuasa dan luar biasa. Narsisme menjadikan individu berada pada suatu kondisi yang bermasalah secara regresif menggunakan dirinya sendiri, bukan orang lain sebagai objek cinta karena narsisme menjadi individu cenderung mencintai dirinya sendiri.

Orang yang memiliki sifat narsis tidak hanya yang gemar memotret diri sendiri lalu mengunggahnya di media sosial, tetapi juga gemar membanggakan diri sendiri pada orang lain. Jennifer Golbeck (Widianti, 2013) mengungkapkan dalam penelitian-penelitian terdahulu, orang-orang bersifat narsis cenderung tidak disukai oleh orang-orang yang mengenalnya.

Ojanen et al. (2012) dalam penelitiannya menyatakan adanya hubungan antara narsisme, temperamen, agresi fisik, dan agresi relasional antar teman sebaya pada remaja. Narsisme memicu munculnya perilaku agresi fisik pada lakilaki, serta agresi fisik dan relasional pada laki-laki dan perempuan.

Setiap individu, terutama pada fase remaja, memiliki kesempatan untuk dapat mengembangkan pengamatan, pikirian, ingatan, dan fantasi ke dalam sebuah perilaku. Perilaku sulit untuk dibatasi karena setiap individu secara naluriah akan menampilkan suatu tindakan sebagai hasil dari pengaktualisasian diri. Bentuk aktualisasi diri setiap remaja berbeda-beda, salah satunya ditampilkan melalui perilaku narsisme agar remaja mendapatkan pengakuan serta pengaguman dari lingkungannya. Dalam kehidupan sosial, tata aturan, nilai, dan norma yang berlaku di masyakarat menjadi batasan bagi remaja dalam berperilaku. Remaja yang berada pada masa transisi rentan dalam 
mengendalikan emosi dan bukan menjadi rahasia umum bahwa perilaku remaja yang labil teraktualisasi pada perilaku narsis.

Pada usia yang berada pada masa transisi, remaja sudah mulai memiliki minat-minat tertentu seperti minat pada penampilan diri, Remaja berusaha untuk dapat berpenampilan semenarik mungkin untuk mendapatkan pengakuan serta daya tarik. Menurut Kernan (Santrock, 1980: 220) "penampilan diri terutama di hadapan teman-teman sebaya merupakan petunjuk yang kuat dari minat remaja dalam sosialisasi”. Remaja mengaktualisasikan minatnya terhadap penampilan diri secara berlebihan memiliki kecenderungan narsis, namun biasanya memiliki permasalahan dengan kepercayaan diri. Halgin \& Whitbourne (2010: 102) menjelaskan bahwa "mereka memiliki penghargaan yang berlebihan terhadap kehidupan mereka sendiri dan terus merasa kesal terhadap orang lain yang mereka rasa lebih sukses, cantik dan cerdas".

Beck, dkk. (Halgin \& Whitbourne, 2010: 103) berasumsi bahwa orangorang dengan narsisme berpegang pada gagasan ketidakmampuan menyesuaikan diri sendiri, termasuk pandangan bahwa mereka adalah orang yang luar biasa yang pantas diperlakukan lebih baik dari pada manusia biasa. Cakupan narsisme lebih luas tidak hanya dipandang dari segi gaya hidup, dan finansial, tetapi juga kekuasaan, prestasi, fisik dan penampilan. Individu yang mempunyai kecenderungan narsisme lebih tertarik dengan hal yang hanya menyangkut dengan kesenangan pribadi. Hal ini juga memberikan pengaruh cukup besar dalam pergaulan sehar-hari dan biasanya tidak memiliki kepedulian terhadap perasaan orang lain.

Masa remaja dikatakan sebagai suatu masa penentu karena pada periode ini seseorang meninggalkan tahap kehidupan anak-anak, menuju ke tahap selanjutnya yaitu tahap kedewasaan. "Masa ini dirasakan sebagai suatu krisis karena belum adanya pegangan, sedangkan kepribadiannya sedang mengalami pembentukan" (Soekanto, 1990: 414). Pada fase ini, remaja memerlukan bimbingan, sehingga sekolah berperan penting untuk membantu siswa yang berada dalam fase remaja untuk dapat menentukan perilaku yang sesuai dengan porsinya.

Berdasarkan fenomena-fenomena yang terjadi, maka dilakukan penelitian terhadap profil perilaku narsisme siswa yang berada pada fase remaja di sekolah menengah pertama, agar dapat mengetahui serta memahami permasalahan 
yang terjadi pada remaja secara lebih mendalam. Penelitian ini sebagai upaya awal guna mencegah perilaku narsisme menjadi suatu kelainan kepribadian pada remaja (siswa SMP) dan implikasinya bagi bimbingan dan konseling.

\section{METODE}

Desain penelitian dalam penelitian ini menggunakan pendekatan kuantitatif. Dalam penelitian ini, data akan dianalisis dan dijelaskan secara akurat dengan menggunakan perhitungan statistik dalam bentuk numerik mengenai gambaran perilaku narsisme remaja dalam bentuk numerik. Penelitian ini menggunakan metode deskriptif, karena peneliti hanya memberikan suatu gambaran mengenai fenomena yang diangkat dalam penelitian tanpa memberikan perlakuan, manipulasi, atau mengubah variabel-varibel bebas.

Populasi penelitian ini adalah seluruh siswa kelas VIII SMP Negeri 29 Bandung Tahun Ajaran 2015/2016. Pertimbangan dalam menentukan populasi penelitian adalah siswa yang duduk di bangku kelas VIII adalah karena siswa kelas VIII berada pada fase remaja yang telah melewati masa anak, dimana siswa berada pada rentang usia I3-I4 tahun. Jumlah siswa kelas VIII SMP Negeri 29 Bandung adalah 324 orang. Untuk mendapatkan gambaran perilaku narsisme, maka sample penelitian yang digunakan dalam penelitian ini adalah dengan menggunakan teknik random sampling. Penggunaan teknik random sampling memberikan peluang kepada setiap anggota populasi untuk dijadikan sebagai sampel penelitian.

Dalam penelitian ini instrumen yang digunakan adalah angket mengenai narsisme yang diturunkan dari aspek-aspek yang dikembangkan oleh Vaknin yang selanjutnya diturunkan menjadi indikator untuk kemudian dijabarkan menjadi butir pernyataan. Dalam Tabel I merupakan aspek dan indikator atau kisi-kisi intrumen yang telah dirancang untuk mengukur narsisme. Angket narsisme berjumlah 58 pernyataan, dengan jumlah pernyataan positif sebanyak 37 positif dan 2 I pernyataan negatif. Skala pengukuran yang digunakan dalam penelitian ini adalah skala Likert. 
Profil Perilaku Narsisme Remaja serta Implikasinya bagi Bimbingan dan Konseling

Tabel I. Kisi-kisi Intrumen Penelitian Narsisme

\begin{tabular}{|c|c|}
\hline Aspek & Indikator \\
\hline \multirow{2}{*}{$\begin{array}{l}\text { Memiliki perasaan } \\
\text { grandiose (perasaan megah) } \\
\text { dan self-important }\end{array}$} & Melebih-lebihkan prestasi dan bakat \\
\hline & $\begin{array}{l}\text { Tuntutan diri untuk di akui sebagai } \\
\text { superior tanpa prestasi sepadan }\end{array}$ \\
\hline \multirow[t]{3}{*}{ Dipenuhi dengan fantasi } & Terobsesi akan ketenaran \\
\hline & Terobsesi dengan keindahan tubuh \\
\hline & Terobsesi dengan kemampuan seks \\
\hline \multirow[t]{2}{*}{$\begin{array}{l}\text { Merasa diri adalah individu } \\
\text { yang khusus dan spesial }\end{array}$} & $\begin{array}{l}\text { Merasa diri paling hebat dibanding orang } \\
\text { lain }\end{array}$ \\
\hline & $\begin{array}{l}\text { Hanya dapat bergaul dengan orang-orang } \\
\text { khusus dengan high status }\end{array}$ \\
\hline \multirow[t]{4}{*}{$\begin{array}{l}\text { Memiliki kebutuhan yang } \\
\text { ekspresif untuk dikagumi }\end{array}$} & $\begin{array}{l}\text { Membutuhkan kekaguman yang } \\
\text { berlebihan dari orang lain }\end{array}$ \\
\hline & $\begin{array}{l}\text { Membutuhkan perhatian yang berlebihan } \\
\text { dari orang lain }\end{array}$ \\
\hline & Ingin menjadi seseorang yang ditakuti \\
\hline & Ingin menjadi seseorang yang terkenal \\
\hline \multirow[t]{2}{*}{$\begin{array}{l}\text { Mengeksploitasi hubungan } \\
\text { interpersonal }\end{array}$} & $\begin{array}{l}\text { Memanfaatkan orang lain untuk mencapai } \\
\text { tujuan sendiri }\end{array}$ \\
\hline & Mengeksploitasi hubungan dengan teman \\
\hline \multirow[t]{3}{*}{ Tidak memiliki rasa empati } & Tidak mau mengakui pilihan orang lain \\
\hline & $\begin{array}{l}\text { Tidak dapat memahami perasaan orang } \\
\text { lain }\end{array}$ \\
\hline & $\begin{array}{l}\text { Tidak dapat memahami kebutuhan orang } \\
\text { lain }\end{array}$ \\
\hline \multirow[t]{2}{*}{ Perasaan iri } & Merasa iri kepada orang lain \\
\hline & $\begin{array}{l}\text { Merasa bahwa orang lain iri terhadapnya } \\
\text { (diri sendiri) }\end{array}$ \\
\hline \multirow[t]{3}{*}{$\begin{array}{l}\text { Berperilaku arogan dan } \\
\text { angkuh }\end{array}$} & $\begin{array}{l}\text { Merasa lebih tahu dibandingkan dengan } \\
\text { orang lain tentang suatu hal }\end{array}$ \\
\hline & Marah saat frustasi \\
\hline & Merendahkan orang lain \\
\hline
\end{tabular}

Instrumen narsisme diuji validitas dan realibilitas. Berdasarkan hasil olah data, maka didapatkan hasil bahwa dari 58 butir item, 42 butir item dinyatakan valid dan 16 butir item dinyatakan tidak valid. Untuk mendapatkan hasil dari uji reliabilitas, perhitungan hanya dilakukan terhadap butir yang dinyatakan valid menggunakan rumus Alpha Cronbach. Berdasarkan kategori interpretasi, maka 
nilai reliabilitas instrument dalam penelitian ini adalah 0,903 termasuk dalam kategori sangat tinggi.

Hasil olah data yang telah diperoleh kemudian dibagi ke dalam tiga kategori yakni tinggi, sedang dan rendah. Untuk dapat menentukan kelompok kategorisasi narsisme remaja dilakukan penentuan skor yakni melalui langkahlangkah (Azwar, 2012:149) seperti pada Tabel 2.

Tabel 2. Kategori Pengelompokan Data

\begin{tabular}{cc}
\hline $\mathrm{X}<(\mu-\mathrm{I}, 0 \sigma)$ & Rendah \\
\hline$(\mu-I, 0 \sigma) \leq \mathrm{X}<(\mu+\mathrm{I}, 0 \sigma)$ & Sedang \\
\hline$(\mu+\mathrm{I}, 0 \sigma) \leq \mathrm{X}$ & Tinggi \\
\hline
\end{tabular}

Dari hasil kalkulasi Tabel I, selanjutnya skor diubah ke dalam skala 100 untuk mendapatkan skor yang sama baik itu pada gambaran secara umum, peraspek serta perindikator dengan rumus: $\frac{\mathrm{X}}{\mathrm{Xmax}} \times 100$.

Maka didapatkan hasil pengelompokan kategori narsisme dengan kategori tinggi, sedang dan rendah yang ditampilkan dalam Tabel 3.

Tabel 3. Kategorisasi Perilaku Narsisme

\begin{tabular}{cc}
\hline Kategori & \multicolumn{1}{c}{ Skor } \\
\hline Tinggi & $74-100$ \\
\hline Sedang & $47-73$ \\
\hline Rendah & $20-46$
\end{tabular}

\section{DISKUSI}

Perolehan secara umum tingkat narsisme siswa Kelas VIII SMP Negeri 29 berada pada kategori sedang dengan skor rata-rata 48. Berikut merupakan profil perilaku narsisme berdasarkan grafik di Gambar I. 


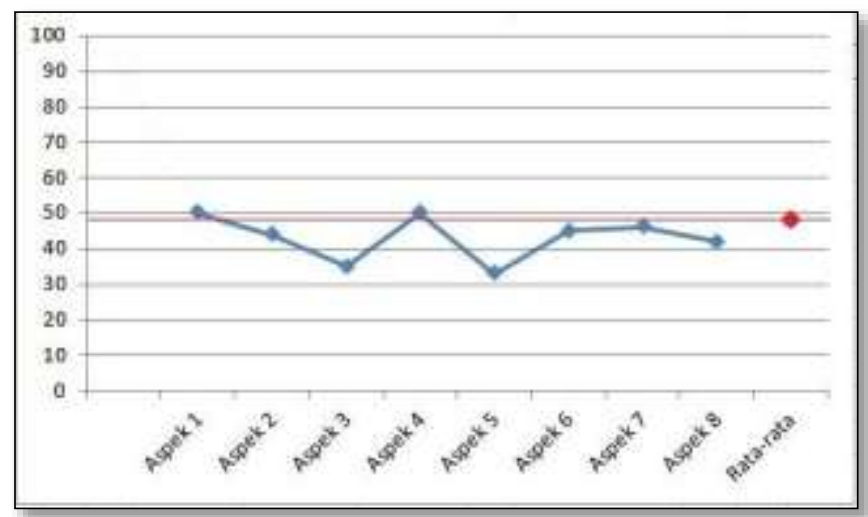

Gambar I. Grafik Profil Perilaku Narsisme Siswa Kelas VIII SMP Negeri 29 Bandung

Deskripsi profil umum narsisme remaja di siswa SMP Negeri 29 Bandung Tahun Ajaran 2015/2016 akan dipaparkan dengan menampilkan jumlah siswa berdasarkan kategori serta persentasi hasil pada masing-masing kategori dalam bentuk Tabel 4.

Tabel 4. Distribusi Tingkat Narsisme Remaja

\begin{tabular}{cccc}
\hline No. & Kategori & Jumlah & Persentasi \\
\hline I & Tinggi & 2 & I.4\% \\
\hline 2 & Sedang & 73 & $53.3 \%$ \\
\hline 3 & Rendah & 62 & $45.3 \%$ \\
\hline
\end{tabular}

Secara umum menunjukan bahwa narsisme remaja berada pada kategori sedang dengan rata-rata nilai adalah 48. Meskipun hasilnya menunjukan berada pada kategori sedang, perlu adanya perhatian khusus agar perilaku narsisme tidak menjadi kategori tinggi karena berdasarkan penelitian, terdapat dua orang siswa yang berada pada kategori tinggi. Siswa yang berada pada masa transisi memberikan pengaruh pada pembentukan karakteristik, respon yang ditimbulkan serta bentuk perilaku pada kehidupan sosial.

Perilaku narsisme didasarkan pada delapan aspek: I) perasaan grandiose dan self-important; 2) fantasi; 3) perasaan sebagai individu yang unik dan special; 4) kebutuhan yang ekspresif untuk dikagumi; 5) mengeksploitasi hubungan interpersonal; 6) ketiadaan empati; 7) perasaan iri; dan 8) perilaku arogan dan angkuh. Setiap aspeknya memiliki jumlah item yang berbeda-beda sehingga klasifikasi untuk menentukan tinggi, sedang dan rendah pada masing-masing 
aspek memiliki skor yang berbeda. Berikut merupakan hasil perolehan tingkat narsisme berdasarkan aspek yang ditampilkan dalam bentul Tabel 4.

Tabel 4. Distribusi Narsisme Remaja Berdasarkan Aspek

\begin{tabular}{|c|c|c|c|c|}
\hline No & Aspek & Kategori & Frekuensi & Persentasi \\
\hline \multirow{3}{*}{ I } & \multirow{3}{*}{ Aspek I } & Tinggi & 8 & $5.8 \%$ \\
\hline & & Sedang & 65 & $47.5 \%$ \\
\hline & & Rendah & 64 & $46.7 \%$ \\
\hline \multirow{3}{*}{2} & \multirow{3}{*}{ Aspek 2} & Tinggi & 3 & $2.2 \%$ \\
\hline & & Sedang & 39 & $28.5 \%$ \\
\hline & & Rendah & 95 & $69.3 \%$ \\
\hline \multirow{3}{*}{3} & \multirow{3}{*}{ Aspek 3} & Tinggi & I & $0.7 \%$ \\
\hline & & Sedang & 37 & $27 \%$ \\
\hline & & Rendah & 98 & $72.3 \%$ \\
\hline \multirow[t]{3}{*}{4} & \multirow[t]{3}{*}{ Aspek 4} & Tinggi & 6 & $4.3 \%$ \\
\hline & & Sedang & 78 & $57 \%$ \\
\hline & & Rendah & 53 & $38.7 \%$ \\
\hline \multirow[t]{3}{*}{5} & \multirow[t]{3}{*}{ Aspek 5} & Tinggi & 0 & $0 \%$ \\
\hline & & Sedang & 13 & $9.5 \%$ \\
\hline & & Rendah & 124 & $90.5 \%$ \\
\hline \multirow[t]{3}{*}{6} & \multirow[t]{3}{*}{ Aspek 6} & Tinggi & I & $0.7 \%$ \\
\hline & & Sedang & 52 & $38 \%$ \\
\hline & & Rendah & 84 & $61.3 \%$ \\
\hline \multirow[t]{3}{*}{7} & \multirow[t]{3}{*}{ Aspek 7} & Tinggi & 3 & $2.2 \%$ \\
\hline & & Sedang & 57 & $41.6 \%$ \\
\hline & & Rendah & 77 & $56.2 \%$ \\
\hline \multirow[t]{3}{*}{8} & \multirow[t]{3}{*}{ Aspek 8} & Tinggi & II & $8 \%$ \\
\hline & & Sedang & 71 & $52 \%$ \\
\hline & & Rendah & 54 & $40 \%$ \\
\hline
\end{tabular}

Aspek pertama, mengenai perasaan grandiose dan self-important. Secara umum aspek ini berada pada kategori sedang dengan nilai rata-rata adalah 10 . Grandiosity dan self-important merupakan ciri khas utama yang ditampilkan dalam narsisme. Kombinasi keduanya merupakan akibat untuk bersikap mementingkan diri sendiri dan perilaku defensive yang ditampilkan pada perilaku narsisme (Myers \& Hill, 20II). Pada aspek ini dijelaskan bahwa timbulnya perasaan sebagai individu yang hebat tidak disertai dengan kesesuaian terhadap potensi atau kompetensi yang dimiliki. Aspek ini termasuk ke dalam kategori tinggi artinya bahwa remaja memiliki kesesuaian terhadap pernyataan yang terdapat pada aspek sehingga dapat diasumsikan bahwa remaja 
menganggap dirinya paling pandai, paling hebat, paling berkuasa, paling bagus, paling segalanya dan adanya sikap mementingkan diri sendiri dibandingkan dengan orang lain. Remaja menampakan adanya perasaan luar biasa bahwa dirinya sebagai individu yang penting dan berlebihan dengan tujuan agar orang lain mengetahuinya.

Aspek kedua, menggambarkan bahwa remaja (siswa SMP) dipenuhi dengan fantasi, penjabaran mengenai aspek ini dibagi menjadi tiga, yakni fantasi akan ketenaran, obsesi dengan keindahan tubuh dan kemampuan seks. Fantasifantasi timbul dari harapan yang kemudian diimajinasikan sebagai upaya untuk meraih kepuasaan. Narsisme erat kaitannya dengan suatu anggapan yang berasal dari diri sendiri dan memiliki kecenderungan untuk menunjukkan sikap yang sangat baik pada penampilan lahiriah atau fisik (Emmos; dalam Apsari 2012).

Narsisme juga merupakan jalan untuk melindungi dan mempertinggi rasa normal pada diri sendiri. Pada aspek ini, rata-rata skor narsisme remaja adalah I3 yang berada pada kategori rendah. Namun meskipun demikian, individu perlu diberikan arahan serta pemahaman untuk dapat mereduksi fantasi serta harapan yang tidak masuk akal. Secara umum aspek kedua berada pada kategori rendah dengan rata-rata nilai adalah 13.

Aspek ketiga, mengenai timbulnya perasaan sebagai individu yang unik dan spesial. Secara umum aspek ketiga berada pada kategori rendah dengan nilai rara-rata adalah 7. Pada dasarnya individu yang narsis menunjukkan sikap mementingkan diri sendiri dan sering mermasalah terhadap keraguan terhadap diri sendiri untuk menjadi individu yang lebih hebat dibandingkan dengan orang lain. Namun demikian dalam teorinya menemukan bahwa keraguan terhadap diri membentuk karakteristik sebagai individu yang penuh dengan rasa percaya diri yang tinggi. Hal ini merupakan topeng karena mereka memiliki penghargaan terhadap diri yang rendah (Davidson; dalam Adi \& Yudiati, 2009). Timbulnya perasaan sebagai individu yang unik dan spesial merupakan suatu asumsi yang dibangun oleh diri sendiri karena mereka merasa sangatlah istimewa, mereka merasa bahwa hanya orang yang memiliki status tinggi yang dapat menghargai kebutuhan dan masalah khusus mereka (Halgin \& Whitbourne, 2010). Pada aspek ini, secara umum siswa termasuk ke dalam kategori rendah dengan ratarata nilai adalah tujuh. 
Aspek keempat, mengenai kebutuhan yang ekspresif untuk dikagumi. Narsisme indentik dengan pujian serta pengaguman, hal ini disebabkan oleh adanya harga diri yang rendah. Jika siswa memiliki penghargaan terhadap dirinya berada pada batas normal pengaguman dan pujian dari orang lain tidaklah diperlukan. Individu dengan kecenderungan narsisme memiliki harga diri yang rendah (Robbins, 200I). Siswa yang termasuk ke dalam kategori tinggi pada aspek ini menunjukkan adanya kebutuhan atas pengakuan dari orang lain demi menaikan harga dirinya. Kekurangan pondasi yang kokoh pada aspek ini mengembangkan jati diri yang salah sehingga timbul anggapan dalam diri untuk senantiasa dikagumi oleh orang lain. Kecenderungan untuk meminta pengaguman serta pujian dari orang lain merupakan bentuk kurangnya penerimaan diri sehingga timbul keinginan untuk memperbaiki kekurangan yang ada pada dirinya (Adi \& Yudiati, 2009). Secara umum pada aspek ini, berada pada kategori sedang dengan nilai rata-rata yakni 20.

Aspek kelima, mengeksploitasi hubungan interpersonal, atau memanfaatkan orang lain agar dapat mencapai tujuannya. Aspek ini memiliki nilai rata-rata 8.2 atau termasuk ke dalam kategori rendah. Hal ini diasumsikan bahwa siswa sibuk untuk mengarahkan diri demi meraih tujuan mereka sendiri namun hubungan dengan orang lain dikesampingkan karena adanya pandangan bahwa orang lain merupakan alat untuk dapat memuaskan diri (Halgin \& Whitbourne, 2010).

Aspek keenam, mendeskripsikan mengenai perilaku yang ditampilkan karena tidak adanya rasa empati. Secara umum pada aspek ini, berada pada kategori rendah dengan rata-rata nilai 14 . Individu dikatakan menampilkan perilaku sehat jika dapat mengerti dan memiliki rasa empati pada perasaan maupun keadaan orang lain. Keterpusatan terhadap diri menjadikan individu tidak menghirauan dunia selain dirinya sendiri dan tidak memiliki rasa empati (Lam, 20I2). Rasa empati wajib dimiliki oleh setiap remaja agar peka terhadap lingkungan sekitarnya. Di sisi lain umumnya remaja mampu mengenali apa yang orang lain rasakan dan pikirkan, namun secara lahiriah menunjukkan sedikit yang langsung bergerak untuk membantu. Mereka kurang pengertian atau perhatian terhadap orang lain disebabkan oleh adanya anggapan bahwa diri mereka lebih tinggi dibandingkan dengan orang lain. Kepercayaan tersebut kemudian menghambat kemampuan mereka untuk merasakan kepekaannya terhadap lingkungan. 
Aspek ketujuh, perasaan iri secara umum berada pada kategori sedang dengan rata-rata nilai adalah 16. Cakupannya adalah perasaan iri terhadap orang lain dan adanya perasaan bahwa orang lain memiliki rasa iri kepada dirinya. Salah satu yang menjadi ciri khas dalam narsisme adalah perasaan iri kepada orang lain, yang secara tidak langsung mendeskripsikan bahwa individu tersebut tidak menikmati serta mensyukuri kehidupannya (Kernberg, 1980). Pada aspek ini individu menampilkan perilaku perasaan terganggu jika ada orang lain yang dianggap lebih hebat, lebih cantik maupun lebih segalanya. Hal tersebut timbul karena adanya keinginan untuk menjadi superior.

Aspek kedelapan, mengenai perilaku arogan dan angkuh yang ditampilkan dalam narsisme. Narsisme dapat menyebabkan remaja menjadi individu yang sombong dan angkuh karena keduanya merupakan karakteristik yang termasuk ke dalam hubungan interpersonal mereka (Halgin \& Whitbourne, 2010). Secara umum aspek ini berada pada kategori sedang dengan perolehan nilai rata-rata adalah 10. Bentuk perilaku yang ditampilkan oleh siswa pada aspek ini adalah timbulnya perasaan sebagai individu yang lebih berpengetahuan dibanding orang lain, tidak dapat mengendalikan emosi terutama ketika marah, dan merendahkan orang lain yang dianggap tidak sepadan.

\section{SIMPULAN}

Tingkat narsisme remaja secara umum berada pada kategori sedang. Setiap aspek mayoritas berada pada kategori sedang, mendekati rendah. Namun meskipun demikian, terdapat dua siswa yang berada pada kategori tinggi. Oleh karena itu, siswa perlu diberikan bantuan serta bimbingan untuk dapat mereduksi perilaku narsisme.

Profil narsisme remaja secara umum berada pada kategori sedang dan rendah. Tingkat narsisme siswa didasarkan pada delapan aspek, hasilnya menunjukan empat aspek berada pada kategori sedang dan empat lainnya berada pada kategori rendah.

Penelitian ini bersifat monovariable yang memberikan keterbatasan untuk dapat mengungkap faktor-faktor yang mempengaruhi narsisme, Adapun faktorfaktor yang mempengaruhinya seperti keluarga maupun pola asuh, sosioekonomi, harga diri serta lingkungan pergaulan Disamping itu, tidak adanya penanganan yang diberikan untuk dapat mereduksi perilaku narsisme kepada 
siswa. Misalnya dengan melakukan berbagai kegiatan bimbingan maupun konseling baik itu secara individual maupun kelompok.

\section{REFERENSI}

Adi, P. S., \& Yudiati, A. E. M. (2009). Harga Diri dan Kecenderungan Narsisme pada Pengguna Friendster. Jurnal Psikologi, 3, 25-32.

Apsari, F. (20I2). Hubungan Antara Kecenderungan Narsisme dengan Minat Membeli Kosmetik Merek Asing pada Pria Metro Seksual. Talenta Psikologi, I(2), I83-202.

Azwar, S. (2012). Penyusunan Skala Psikologi. Yogyakarta : Pustaka Pelajar.

Halgin, R \& Whitbourne, S. (2010). Psikologi Abnormal. Jakarta: Salemba Humanika.

Kernberg, O. (1980). Borderline Conditions and Pathological Narcissism. Jason Aronson, Inc: New York.

Lam, Z. K. W. (20I2). Narcissm and Romantic Relationship: The Mediating Role of Perception Discrepancy. Discovery - SS Student E-Journal, I ( ), I-20.

Ojanen, T., Findley, D., \& Fuller, S. (20I2). Physical and relational aggression in early adolescence: Associations with narcissism, temperament, and social goals. Aggressive behavior, 38(2), 99-1 07.

Robbins, R. (200I). Personality Correlate of Self-esteem. Journal of Reseach in Personality, 33, 468-482.

Santrock, J. W. (1980). Psikologi Perkembangan. Jakarta: Erlangga.

Soekanto, S. (1990). Sosiologi Suatu Pengantar. Jakarta: Rajawali Pers.

Vaknin, S. (2007). Malignant self love: Narcissism revisited. Macedonia: Narcissus Publishing.

Widianti, R. (20I3). Apa Kata Psikolog Soal Foto Narsis di Jejaring Sosial?. [Online]. Tersedia: $\quad$ http://health.kompas.com/read/20I3/I2/I8/I I II30 I/Apa. Kata.Psikolog.soal.Foto.Narsis.di.Jejaring.Sosial. [I5 April 2015]. 